\title{
Two keys to attracting the Baliem people
}

\author{
Dorus Rumbiak
}

There are two keys that can be used to captivate the hearts of the Dani people of the Baliem Valley. The first is to approach them through their elders or community leaders, and the second, through their children. Over nearly 25 years working as a civil servant in the Baliem Valley, I have rarely seen people of Wamena berating or beating their children, no matter how naughty they behave. They never even so much as lay a hand on their children.

The importance accorded to children makes it not uncommon for a husband to beat his wife because she cannot get pregnant. As a result of this, husbands are allowed to marry numerous times for the sake of having children. In Dani families, husbands are allowed to remarry. In fact it is sometimes the wife herself who asks her husband to remarry, to add a wife! His wife is looking for a woman to serve as a wife for her husband, so she can get help with the heavy work, such as feeding the pigs, as her husband gets wealthier. There are Dani men who have had as many as 40 wives, like the great tribal chieftan, Harireak, and some, like Okumnyare, who have married up to 33 times.

In light of all this, I used Dani children as a way to engage the community here to cooperate. I interacted with their children. Many of them I adopted as foster children. One of my former foster children became a bupati (district head, regent), and many others became civil servants. I took them under my wing, fostered them, and even married them off. That was the key I used.

This approach appealed to them. And the foster care was not merely foster care, but had to be true fostering; I regarded them as my own children. When I was in Wamena, they received me as a father. So, if we did not understand their situation or had not worked long in their place, we had to educate the local people in such a way that they could serve as 
keys for us to enter their worlds. So, everywhere I went I took on children to foster. I just picked from among the young ones, the little ones, then let them go to school and covered their food, clothing, and so on.

When I was first placed in Wamena as a civil servant, my main task was to maintain security across the area in places where tribal warfare occurred. So wherever tribes were at war, I was there. Basically I would go pretty much everywhere. But I had to learn their ways of resolving the problems that led them to engage in ongoing warfare. Usually, people said that tribal wars happened because of murders, problems over women, or people stealing pigs.

But we had to find out the basics of the relationship between women and pigs. I learned why the pig was so important in Dani society. Indeed in Dani marriages, pigs constituted the main property. Pigs were extremely important throughout the mountainous areas. As far as I know, human life and society here revolved around pigs. Yet, on the other hand, I also saw that the people who kept pigs were people who lived in permanent settlements, unlike the nomadic people who lived in the Mamberamo area. So I knew that they lived settled lives. And this meant that they were bound by patterns that governed their lives in that particular place.

I then looked for them, to meet them. I did not address them as tribal chiefs or clan leaders (orang kaya) because they said: 'Address us as "bapak" (father). That's right. We won't call you "sir", we'll call you "son".' I felt these were harmonious relationships, and they were what I used. My success in drawing the community closer astonished Controleur Gonsalvez, my superior in Wamena. 'Ah, Pak Rumbiak can go anywhere,' said Mr. Gonsalvez, 'he travels with only two policemen but he feels no fear!' I was free to go and meet with the people because I used that approach.

SCHOOL IN A REFUGEE SETTLEMENT

I originally came from Biak, but during World War II we were evacuated to Pasi island in Padaido-Atas. And it was on the island that I attended primary school Then the government opened a Jongens Vervolgschool (JVVS, follow-up school for boys) in Korido. In 1950 all the children who graduated from the third grade in primary school took exams to get into 
the JVVS in Korido. The journey to Korido was quite far and you had to go there by rowboat. Bearing in mind how exhausting my parents' troubles to register me were, I was determined to learn so I could truly achieve good results. I passed the entrance exam and was accepted at the school in 1950, and graduated in 1953.

After graduating JVVS I entered OSIBA at the request of the government. OSIBA was the continuation of the Bestuursschool (School for Administrators) that had been opened in the town of Nica (Sentani). Since the Dutch government wanted to extend the Bestuursschool, they opened an opportunity for students who graduated from the third grade at JVVS to go on to the Bestuursschool by following a five-year course. The government later changed the name Bestuursschool to Opleidingsschool voor Inheemse Bestuursambtenaren (OSIBA, School for Indigenous Administrators). I attended school at OSIBA with all of the costs of education, meals, and holidays borne by the government.

Actually, I am the one who chose OSIBA. Before that I was chosen to enter the Lagere Technische School (LTS, Lower Technical School), but I thought that the training I had received at JVVS was not appropriate for entering the LTS. Moreover, the ones who were given priority were the children whose parents were teachers, but not us village children. Although my final exam results at JVVS were excellent, they wanted to send me to a vocational LTS in Kotaraja. But I could not envision going to the LTS. It happened that there was a demand for students for the OSIBA school for civil servants. I went before the hoofd plaatselijk bestuur (HPB, sub-division administrative head) - whose name I have forgotten in 1953. He said, 'Oh, there is still a demand and there are still openings for people from Biak.' After they checked my qualifications, and saw that my final exam scores were good, I was sent to OSIBA.

I attended school at OSIBA for five years, with one year of practice. I entered in 1953, and in 1955 I did one year of practice in Fakfak, an area I did not yet know. For the year I worked under Bapak Arnold Mampioper. At the time, Mr. Woelders served as the controleur (HPB) there. I worked under Mr. Mampioper who was then the district head there. After the one-year practice period, I returned to my studies for two years and successfully completed them. 


\section{MOTIVATED BY FILMS ABOUT AFRICA}

During those two years of study I began getting acquainted with the hinterlands through photos by HPB F. Veldkamp. During that time he made a visit to see the church mission post and government post that opened in Wamena in 1957. On his visit he took photos and filmed. Then Mr. den Haan, the controleur in Wisselmeren (Paniai), brought people from Paniai to our school. Controleur den Haan was famous in Enarotali (the capital city of Wisselmeren). Usually, people called him 'Controleur Cowboy'. He was well known for travelling wearing only swimming trunks! Yes, it had also been written that he was 'de koning der Kapaukus' or king of the Kapauku people. Then I said, 'I will become the king of the Dani!'

So those were interesting experiences. We also saw some films about Africa. I heard the story of Livingstone, who went through the African continent. All of these provided useful lessons for going among the people in Wamena. But eventually it would be asked, who was responsible there? Surely, the Papuans themselves knew. People from outside could not get much done, but Papuans would do more.

That's how the idea arose for me to go into the Baliem valley. But I still had to attend two more years of school at OSIBA. Upon finishing school, the grades I got were fairly high, namely, 9-8-9-7. I graduated cum laude (with honours). I still have the diploma. My preference to serve in the interior became increasingly close to my heart. And since I had graduated cum laude I could make my own choice between two locations, Enarotali or Wamena in the Baliem Valley. I chose to go to the Baliem Valley.

My success in achieving high grades at OSIBA made some police officers who were my professors at OSIBA ask me to continue school to become a policeman (an inspector) in the context of Papuanisation. I was the only one chosen for this course because I had obtained a nine in police science and police practice. 'Ah, Mr. Rumbiak here would make a good policeman,' they said.

But my heart was not drawn in that direction. I disliked people deferring to me and disliked constantly deferring to people. After I had been working for about six months, Controleur Gonsalvez came. He said: 'I heard from the Office of Home Affairs that I had one allotment from the OSIBA graduates, by the name of Dorus. They said that he has now joined the police. Hey, that can't be! He's my employee, the allotment I'm supposed to receive.' 
He looked for me in the police ranks, found me, and said: 'Get ready now! In one week you'll leave for Wamena, provided you take malaria pills first so you won't come down with malaria.' And so it was that I left for Wamena. That was the beginning of my placement as a graduate of the third OSIBA class.

The idea of developing the people of the interior was linked to the responsibility for bringing the people of the interior into the modern world. But what about the conditions of the people in the interior themselves? They were not at the same level as those of us who lived on the coast. True, those of us on the coast (Biak people) were not that advanced either, we had no universities yet. So it really was very difficult. Were we capable of realizing such beautiful ideas? Indeed, compared with Papua New Guinea (PNG), we were far more advanced. I had seen people from PNG who visited Hollandia (Jayapura) at the time, and they still wore loincloths and their police went about with no weapons.

If I compared them with our people in the political meetings that were held in those days in West Papua, we were far more advanced than Papua New Guinea. We had greater freedom than they did in PNG. Over there at that time there was still strong discrimination. Our education in the west was more progressive. When we went to school we already had an idea of what we wanted to become in the future. If we wanted to become civil servants, that was already evident from our interactions at school. Those of us in the schools were students who came from Merauke, Jayapura, Sorong, Biak, Serui, and so on. We had distinct tribal languages, but we got along fine, and our working language was Dutch, although the Indonesian language might also be used.

\section{FIRST EXPERIENCES IN WAMENA}

When I arrived in Wamena for the first time I saw that the people in the Baliem Valley were separated into groups and they were mutually antagonistic. Such conditions made it difficult to resolve problems. So the idea of 'pacification' was proposed at that time. In the pacification programme no Dutch person dared to make a decision. It was the Papuans themselves who made the decisions. If a Dutch person did it, later Mr. Gonsalvez would be the one who was blamed. 
At that time there was a Dani man called Pung Masilone. He banned the Dutch government from passing through his place. At the time Mr. Golsalvez said to me: 'Brother Dorus, you stay to mind the post.' In those days it was not a government centre like it is today. In those days it was just a temporary post for the government. Mr. Gonsalvez left and I remained. He wanted to see the person who had said that if the government came, he would strike the government officer.

And it was true, Pung Masilone struck Mr. Gonsalvez. When Mr. Golsalvez crossed his fence, Pung Masilone came closer. Rather than exposing himself to risk, right, Gonsalvez fired his gun. And after he returned to the post he said: 'Alas, Pak Dorus, I can't pass through there anymore.' I said: 'Ah, if that's the way it is, I can do it.' I could deal with it, I could enter difficult areas. Because I had the 'keys', that is, I had learned how to identify the key persons, people who were the keys to the community. If they had a sense of affection toward us, we could be allowed to just come on in. That way there was no need to worry about a thing. If someone was angry, he would say so. I could also speak a bit of the Dani language.

The Dani people dubbed Gonsalvez atemusi, meaning a hothead. Really, Gonsalves was someone who could not hide his feelings. When he was angry, he would be overtly angry, but he had a good heart. I studied him up close, but he was a good person. The Dani people who were part of Mr. Gonsalvez' joint patrol declared Mr. Gonsalvez guilty. Mr. Gonsalvez was also examined by the prosecution. They summoned him immediately. But he said: 'I don't know anything about the incident. I don't have anything to say because I don't know. So I don't need to take part in discussing the matter.'

Based on the information from the witnesses, Gonsalvez shot one person and the police shot one person. So two people were shot dead. I tried to ensure that no more shooting would be allowed to occur in the Baliem Valley. Although I was his subordinate, I clashed with him. He acted quickly as the person in the front line, while I was usually in the rear. Although the Dani might not like me because they saw me as a newcomer there, I had to be able to speak the Dani language a bit, so I could approach them. You see, the main goal was to bring people of the interior to a higher understanding of the state and so on. When you think about it, it was an impossible thing. 
My presence as an administrator really pleased the people. But it was hard for us to settle their problems. If I settled them using the pattern of people at war, well I did not want to do that because it was none of my business. It was their business. So I instructed them that when they came they should not bring any spears, arrows or sharp things for fighting. I asked them to talk to their hearts' content, and finally I would come to a decision. I wanted to hear their claims, commensurate with the casualties and losses of each party. So the claims of loss had to be equivalent. If there was a party with a greater number of victims, they demanded payment in keeping with these, and once they were paid they would be reconciled. Yes, that is the way we dealt with it.

At that time we were not yet bringing cases to court. Because that would have been something new to them. According to them, prison sentences could teach people to become criminals. Because people said: 'Well, in prison the meals are tasty!' So, at that time we did not bring the perpetrators of crimes to court. I punished the perpetrator with a sentence of one to two weeks of hard labour, for example, plantation work or other jobs. And he would be forbidden to see his family. So the perpetrators did not go to prison. We should not be in a hurry to send people to prison. We had to move slowly. Prison sentences could be applied later on.

Mr. Gonsalvez once took them to Lere, a district in the vicinity of Jayapura. In Lere they were given all kinds of food to eat, but they cried every day. After around six months a decision came down from the court that they be brought back to the Baliem Valley. But they still never forgot about Lere and all they experienced there.

Exile to Lere involved a type of conscript labour as punishment. The government at that time was planning to make an airfield there. At that time I was interviewed by Mr. Merkelijn from the Bureau Bevolkingszaken (Office of Population Affairs). I said that if plans to build the airstrip were discussed, then the work should be started too. If we talked about it that day but did not start to work on even a single metre, then it was a failure. That was the principle I used. So work on the airfield was one form of punishment that was applied in the Baliem Valley. 
Because of how difficult communications were in those days, the plan emerged to create an airfield to open the interior from its isolation, so that the mutual hostilities among the tribes would disappear on their own because the people would have other activities to keep them busy. They saw for themselves that they received wages for working on building the airfield, which they could use to buy axes, mirrors, handkerchiefs and other fine goods. We paid them in contact articles. Yes, because at that time they were not yet familiar with money, so we paid them in the cowrie shells that they used as currency. The Protestant mission, CAMA (Christian and Missionary Alliance) and the Roman Catholic Mission already had their own airstrip to meet their own needs, but not those of the people. The presence of missionaries there was not only to spread Christianity. In 1960 we held a conference and decided to build a relationship between regions, between the centre (Hollandia) and the region (Wamena), and between Protestant missions (zending) and Catholic missions. Yes, there was good cooperation between the Protestant and Catholic missions.

So we developed cooperation between the government and the Protestant and Catholic missionary agencies. Those of us in the government worked together with the Protestant missionary agencies and Catholic missions on building roads and building airfields. They provided shovels, machetes, and tools for the people to work with, but the payments were alotted by the government. So it was the government that paid wages to the people who worked. This cooperation was realized through the conference held in 1960. The conference bore the English name: 'The Conference between Government and Missionaries'. During the conference measures were taken to open new government posts.

Regarding plans to open the airfield, I always consulted with the people first. I explained that if there was an airfield, airplanes could bring in many things such as salt, cowrie shells, axes, machetes for gardening, shovels, and all sorts of other goods. I spoke to the tribal chiefs first. And if they approved, we began working. Wamena was a former battleground that had been abandoned by its residents. Then residents came from all directions and told us: 'We will give this land for the building of the airfield.' Yes, they approved it because it was in the public interest, and this was enough to rule out individual interests. The settlements based 
there gradually moved away over time because the place was used to set up tents for the people who came to work on the construction of the airfield. Yes, and later on the area was urbanized. Back then I was the one who surveyed the land area for the town of Wamena. All of it was my doing. It was after the new airfield opened that we saw the introduction of change.

\section{EXCHANGING ADAT LAND FOR AXES}

At that time, the agreement to open the airfield, including the transfer of adat land, was not set in writing. What did exist was only a general statement. A small airfield was already open at the time. But because we wanted to bring in large planes, we needed a bigger airfield. As compensation for the land, the government gave axes and machetes to the tribal chiefs. I did not witness that myself. It was discussed by the controleur with the tribal chiefs before I arrived. When the airfield began to be cleared, the whole community acknowledged that the airfield was in their interests. And they did not require certificates for the land taken by the government to build the town of Wamena. At the time I thought: 'Papua is so vast, there is no need for land certificates to be issued.'

When problems later arose in Wamena, when people claimed ownership rights over the communal land taken by the government to build the town of Wamena, it was due to the government's own acts. There was a civil servant from Ambon who instigated the problem. At the time he was serving as the camat or sub-district head there. Secretly, he requested that certificates be issued for lands that had no certificates yet. There were no land certificates for any of the area we determined at the time. Our goal at the time was just to develop the town of Wamena first. Not to make grandiose promises to the community but have them feel no benefits later on. Not to go to the point of causing the government to suffer losses if something were to happen that caused the government to leave. Later on, once the town of Wamena was developed and the people who owned the land came to demand payment for the land, only then would certificates be issued. At the time no land certificates were made because Wamena was a newly opened government post. I did not know if any compensation price had been provided for Wamena. 
Well, at that time they had made no claims yet because back then I was the one who opened the place up and I myself spoke with the land owners and made declarations (surat pernyataan) with them, stating that no payment was made for the land. During the time I served in Wamena, the land owners made no claims. Only now, since I went away, have they come to stake claims. The fact that they made no claims yet at the time that was their right. Because I was the one who opened the valley, I still remember the land area that I surveyed. It may well have changed since then due to the expansion of the town and the airfield. But I still know the boundaries of the land, where I stood when I measured the land. When the airfield was completed, it seemed that the situation began to be secure throughout the valley, although here and there, there was still a little confusion. But as a civil servant, I saw that in order to succeed we had to work for a long time in a given place and not keep moving frequently from place to place.

Yes, perhaps because I loved the beauty of nature, it became a hobby that when I came home from patrols (official trips) I liked to walk around in the mountains, enjoying the natural beauty of the Baliem Valley. That is what enabled me to tolerate working there for such a long time. I effectively worked there for 18 years. And if this is combined with the seven-year interval of my studies, then it comes to 25 years. But it was an interesting experience, which I engaged in so that society could move forward. Nowadays the young people from Wamena here (in Biak) always come around to look for me if there are any problems. They say to me 'Bapak, come back to Wamena!' Then I reply: 'Yeah, I'd like to return but I do not want to be glorified'. That is why I do not want to show up over there.

\section{THE TRANSFER OF PAPUA}

Before Papua was handed over to Indonesia in 1962, I was transferred to serve as the district head at the level of a Dutchman in Bokondini, to replace Mr. B. Huizinga. According to the transfer agreement of the UN (New York Agreement) on 15 August 1962, the Netherlands had to transfer West Papua to Indonesia. Following the transfer, I was appointed as the replacement of Controleur L.F.B. Dubbeldam. He did not transfer 
anything to me, except upon my arrival in Wamena, when I took a few notes from him in the airplane, and after that he departed.

There was no Memorie van Overgave (Memorandum of Transfer). Nor was there any transfer ceremony, because the Dutch were forced to get out. And I didn't I get to have or keep the records because they were all taken by the UN people.

The entry of the United Nations Temporary Executive Authority (UNTEA) put us at a disadvantage because the decision was made without first consulting us. The Dutch government appeared to be fearful because it had already experienced difficulties in maintaining its colonial territories. Once there was a letter from the Ministerie van Overzeese Rijksdelen (Ministry of Overseas Regions) in the Netherlands giving orders to address parts of the region that would not be handed over to Indonesia. That was what formed the basis for opening up the Baliem Valley under Controleur Dr. de Bruyn. I read the approach guidelines by Mr. de Bruyn. These were the guidelines for the approach used by the Protestant missions and the government to enter the area. And I also used the same guidelines for working in Wamena.

The UN (UNTEA) period brought changes that we did not understand at all. Perhaps this was because the Netherlands did not create an overall Memorandum of Transfer explaining its abandonment of Papua. It simply did not exist. They all just suddenly left.

When the UNTEA came in, some of them replaced the Dutch officials, some became controllers, and some became residents. I still remember two British people, one of whom was called Mr. Carter. He had once served as the governor of Malacca. I saw that Mr. Carter and the others were working cautiously because they did not know what steps would be taken by the Indonesian government. They complied with all the instructions. They only worked for six months. In fact they left before the six months was up. Mr. Carter was replaced by Mr. Rins and then Rins was replaced. So they did not stay long. Within three months they were transferred again.

\section{THE LOOTING OF DUTCH HOMES}

Once the Indonesian military and Indonesian officials came in, I saw that what happened was just looting. They looted all the houses. They 
went home carrying big suitcases filled with goods the Dutch had left behind, because when the Dutch left, they never brought anything home. The Indonesian army and officials had only come to plunder. We were astonished by this.

Papuans also entered the abandoned Dutch homes but they did not loot them. But I myself witnessed looting on a grand scale. We were all angry because the Indonesians took away everything that was considered important. Is that what is called victory in war? We (Papuan officials) stayed calm and performed our routine jobs.

We were educated, and guided by our faith as Christians, we remained resilient in spite of all these events and circumstances. God's eyes were not closed to us. God also came to see and feel the situation we were experiencing. If we hadn't had strong faith, we might have collapsed. That was our experience at that time. We steeled our hearts, in the faith that that the whole situation would surely pass. Well, at that time all sorts of corruption occurred too. We were working under extraordinary pressures. That was how I experienced working in the government in the Indonesian period. My friend, Decky Zonggonao, who was arrested and imprisoned at that time, said that only God could change the situation. We believed that the situation would soon pass, even though it seemed impossible. I always looked at it that way.

The most severe times were from 1962 to 1969. Regarding the implementation of the Act of Free Choice (Penentuan Pendapat Rakyat, 1969), that was extraordinary because so many things were blatantly hidden from us. I resumed my duties in Wamena after serving for three months in Bokondini. As a result of the handover (from the Netherlands to the UNTEA) I was pulled back to serve in Wamena. But during the Act of Free Choice I attended the first class of studies at the Akademi Pemerintahan Dalam Negeri (APDN, Academy of Domestic Government) in Malang.

Regarding the implementation of the Act of Free Choice I myself do not know much because we were put into prison beforehand. Basically, all the leading people that were thought to have knowledge and experience in the government or public sectors were put in prison, in police and military detention centres. I was detained for three months in the military police detention centre (CPM) in Kloofkamp Jayapura, then known as Sukarnopura. By the time I was released from custody, one of my fellow students had already completed his education. I did not want 
to fall behind in my studies. Because of that, I worked hard and managed to graduate from my course of education as well. I was given amnesty and allowed to keep learning.

\section{CHAOS IN WAMENA}

In 1975 I returned from my studies in Java. In 1973 there was great turbulence in Wamena. Many people were killed and churches were burned down. I was ordered to go there but I did not want to go. I said to the government: 'Didn't you suspect I was a member of the OPM rebelling against you, so that I was arrested? I do not want to go to fix the situation in Wamena, which you have devastated. I am not the one who caused the problems there.' But the government said: 'You must go, because if you don't go, the situation in the interior will remain in chaos.' So yes, I went there and worked as the sekwilda (regional secretary) for eight years in Wamena.

Many violations of their customary law were committed there, such as bothering the wives and daughters of the local population. Soldiers and policemen on duty at the outposts there had no sense of decency. Those of us who opened the Baliem Valley had worked there without bringing our wives, but we did not behave like that. That was because we knew that if we wanted to work there for a long time and wanted to succeed, we had to respect the community along with its adat laws. If we did not do that, the people would feel we were insulting them. Because they had continually violated the adat laws of the community, seven members of the police were kidnapped. That was the consequence of misconduct towards their wives and daughters. When they killed there was no mercy because they were extremely offended. We knew their adat because we got on well with them. When we talked with them, we talked with the elders. They considered it very wrong to talk to young unmarried women. One should not make repeated attempts to talk to people's wives. Their husbands were extremely jealous! And very dangerous, when a husband forced his wife to admit what she had done.

During the period of the Dutch administration, I had succeeded in developing a good approach to the local inhabitants. When I was ordered to go the Baliem Valley in 1975 following the great turbulance that had happened there, I succeeded in securing the Baliem Valley. First, I saw 
that there was one crucial thing in the events that had taken place in the Baliem Valley. What had happened was a war between people who were not Christians fighting against Christians. And I, as a member of the Christian and Missionary Alliance (CAMA) Gospel Tabernacle Church, opened my house as a place of worship. The local people came and said to me: 'Bapak, don't try to hold church services here. That's what made a lot of church leaders here get kidnapped and a lot of churches get burned down. So, bapak, don't ever open this place for church services.' I said to them: 'No, we need to return to God. Because if we don't return to God, this valley will go to the devil! If you don't revere God, you will all perish!' Then I established a church named Gereja Efata.

It started with two families and has now grown into a large congregation. I told the Dani that it was a church building for Dani people who were members of the CAMA Gospel Tabernacle Church. I said that if we started working in this way, everything would be alright because God would be with us, because we accepted God. Why should we still be afraid of anything? I only knew one thing, that is, that God led and saved us. God said not to fear them, for they could kill the body, but did not have the power to kill the soul. In our administration we used many verses from the book of proverbs of Solomon. Solomon was a wise and rich king, and he had many wives! We used a lot of King Solomon's advice in our daily work. Good morals were very important. But it was not easy to change the evil-loving nature of human beings. So we had to start from scratch in building the community.

After I returned from Jakarta, I received a promotion because of my role as a designer in the establishment of sub-districts and villages in the province of Irian Jaya. I received the promotion to go and study at Institut Ilmu Pemerintahan (IIP, Institute of Governmental Studies) in Jakarta. Once back from IIP, I served as head of the village administration division at the government bureau in Jayapura. And in the context of that job I continued the programme of establishing villages in the province of Irian Jaya. After three and a half years of working and completing the village establishment programme, I was appointed as regional secretary of Wamena, and I went to resolve the events that had taken place in Wamena. 


\section{THE ESTABLISHMENT OF VILLAGES}

I left to study at IIP in 1972 and completed these studies in 1975 and returned to Jayapura. At that time, the plans for the establishment of the villages were completed, and a team from the central government came and held a meeting with all the bupati (regents or district heads). Many of the bupati said: 'Oh, this cannot be! These villages cannot be united!' And when Governor Frans Kasiepo said to me: 'Some of the bupati have objections to the plans, little brother, how can these be resolved?' I answered him: 'Easy. The important thing is that they are willing to reach an agreement. This is only a concept on paper. We'll just specify the regional boundaries first. Determining and establishing the villages will be worked out gradually.'

So, the existing sub-districts and districts were unified to form $k e^{-}$ camatan (sub-districts of the Indonesian kabupaten regencies or districts), and the kampung were turned into desa (villages). Then we looked at linguistic and religious similarities, so that the merged kampung would stay together, and not give rise to problems in the future. Those initially appointed as village heads were influential people such as korano (village heads) and ondoafi (adat leaders). The village people themselves proposed the candidates. We in the government did not impose them. Whoever was considered suitable, such as a well-educated native of the village itself, could be nominated to serve as the village head.

We knew that the villagers did not know much about government matters. I was usually tasked by the province to provide upgrading courses to the village heads. I did not give courses based on written materials, but came in and told them they were to listen to stories about the role of a village head. I used this method because the levels of education and knowledge among them were varied. And it would be very time consuming for the village heads to learn all about village government. And it was not feasible. It could not be forced. So we just taught the practice of village governance to village heads. I had worked for years in the Dutch period and I knew about village governance in practice. Since then, I have worked under Governor Frans Kasiepo, Governor Acub Zainal, and Governor Sutran (the ex-bupati of Trenggalek in East Java).

At that time all of the important positions were held by people from the centre, not by people from the local regions. Most of the officials around the governor came from outside the area. Local people who 
were given important positions included those who had already completed their education as well as those who had not. But they remained entrenched in their positions because of their relationships with people at the top, for example, the head of the Government Bureau was the governor's son-in-law. And all of this was regulated by Jakarta. Papua was like a leaf, while the tree was in Jakarta. And this could not be changed.

\section{INTRODUCING A MARKETING SYSTEM}

The changes that occurred really did not directly familiarize people with the new culture. But at least they got to know its requirements, for example, that for their children to attend school they needed school fees and school uniforms. Therefore they had to learn how to earn money. Then we encouraged them to plant vegetables, raise fish and whatever else they could do to make money. They had to learn from the new immigrants how to make money by their own efforts. If you go to Wamena you can see the coffee trees that I planted in 1960. I planted a lot of coffee in Kurima and Bokondini. I told the people to plant coffee. The head of the agriculture department at the time, Mr. van der Sluys, said that the coffee seedlings were brought from PNG, and would thrive if they were planted here. It was a high quality type of coffee and after it was ground it could be transported by airplane.

That is what encouraged me to invite the people to plant coffee in Bokondini. We wanted to introduce farming and marketing to the local residents so they would know that they could make money this way. Whereas before, they asked for 100 rupiah on average, now they were asking for five thousand rupiah. That was a sign that they understood the value of money in market exchanges. However, the small traders had real difficulties entering a market dominated by big traders from outside the area. Conditions like this occurred in the large towns such as Biak and Jayapura as well as Wamena. The Papuans had only just learned the marketing system and they felt marginalized by the immigrants. It was not possible for the Papuans to open large shops right away. They had to learn from small-scale sales enterprises.

We were happy when Papuans took part in the market by selling their products. In Wamena I banned Makasarese merchants from selling their goods in the public market. That place was provided for Papuans only. 
Let them learn how to market their products. The traders from outside must not forcibly take goods from the local people at very low prices and then sell them at high prices in the market. Nor should they give money in advance to local residents by ordering their goods. Those were not good ways to educate them. Later on when they expanded, they could do things like this. But we did not want to lay a faulty foundation.

In Wamena I also tried to ban the importation of alcoholic drinks. The bupati said there were certain individuals who were bringing in alcohol. Alcohol can destroy human lives. So I all-out banned it. I told the bupati that if alcohol was imported here, I would go home because I did not want to risk being held liable. I told him that the people who were bringing in alcohol were intent on destroying the entire way of life of the people here. When they drank alcohol, they got drunk, killed people, and could become very evil people. The bupati would never find out the results of his decision to import alcohol here. The chief of police and commander of the district military command supported me. And at last Wamena was safe. I said that in the government one must not merely think about money alone.

\section{GIVE PEOPLE RESPONSIBILITIES}

When I was in government, we all depended on the central government. There were no local revenues. This applied to Wamena and almost the entire province. According to the laws on the balancing of finances between the central and local governments in the republic, 97.25 percent of local revenues went to the centre. The provincial government got 2.25 percent and the kabupaten 0.02 percent. So local areas received nothing at all.

Those areas of Indonesia that were acquainted with international commerce could advance. But it was difficult for Papua, which was still so backward despite its wealth in forest products and mining resources, which required technology (and substantial amounts of capital) to process, as is currently being done at Freeport by foreign companies.

Our economy revolved solely around the economics of consumption. But we could do simple things to make money, such as planting soybeans. Many people in the world required soybeans. Thus, Papuans were told to plant soybeans, which could be picked in three months, and they would 
have money. That was easier to do than having to wait for big projects that involved all kinds of research that took years to complete.

The same went for fisheries. What was being produced was only for personal consumption, but could not be sold outside. This was due to a lack of modern equipment. What's more, in Papua people worked on their own and not in groups as in other areas. In my view that was where the difficulty lay here. Pig and poultry breeding could also be developed here. The same went for banana projects, because America and Europe needed bananas. But the government did not see that it was the government's job to develop the economy in order to provide prosperity to its people. I think that is what all human beings need. Prosperity means that people have enough to eat so ideas of committing offenses and crimes do not enter their minds.

As for the future of Papua, well, I cannot see that far ahead, since Papua has remained underdeveloped while governance and development in other areas in Indonesia have advanced. Development in Papua must directly benefit society. The name of the people must not be used for self-interest. For example, in my experience, I have seen monies for the people in a village being spent by the village head while the villagers got nothing at all.

Programmes ought to be carried out by the government together with rural communities. In livestock-breeding projects, for example, government officials should provide information on how to raise cattle. So the government provides funds and technical assistance. Yet it is not the government that is responsible, but the community groups found there. It would be as if the enterprise were semi-governmental - partly handled by the government and partly by community groups. The government would provide funds, equipment and technical personnel, while the people provided the land and labour to do the work. Outsiders say that the people of Papua are not capable of that yet. OK yes, but how can we become capable if only one or two people are sent to attend training, and upon returning from their studies, they work for themselves and not for the many, and they have mastered only techniques but not the community? Therefore, projects should be done directly in the field.

Yet based on my experience, I know that the money is spent by the agencies concerned to finance return trip expenses, to the point that there is no physical development. Yes, this is the mistake that is made. Actually, what is needed to develop Papua is to develop the people's 
economy, so that people are capable of meeting their own needs. Do not develop things only for the purpose of exports to Europe, India, and so forth. Because the proceeds from exports are used to purchase heavy equipment, but not things for the people.

Government programmes should be based on what is good in the interests of the people. This is our duty as indigenous Papuans who work in government. We must work in the interests of our people in the ever changing modern world. The legislation and policies set by Jakarta are at times in conflict with the needs in the region. 